\title{
The behavior of Sotalia guianensis (Van Bénéden) in Pernambuco coastal waters, Brazil, and a further analysis of its reaction to boat traffic
}

\author{
Janaina P. Araújo ${ }^{1}$; Antonio Souto ${ }^{2}$; Lena Geise ${ }^{3}$; Maria Elisabeth Araújo ${ }^{1}$ \\ ${ }^{1}$ Departamento de Oceanografia, Universidade Federal de Pernambuco. Avenida Arquitetura, Cidade Universitária, 50730- \\ 540 Recife, Pernambuco, Brasil. E-mail: janainabio@yahoo.com.br; betharau@terra.com.br \\ 2 Departamento de Zoologia, Centro de Ciências Biológicas, Universidade Federal de Pernambuco. Rua Professor Moraes \\ Rego, Cidade Universitária, 50670-420 Recife, Pernambuco, Brasil. E-mail: asouto@elogica.com.br \\ ${ }^{3}$ Departamento de Zoologia, Instituto de Biologia, Universidade do Estado do Rio de Janeiro. Rua São Francisco Xavier 524, \\ Maracanã, 20550-013 Rio de Janeiro, Rio de Janeiro, Brasil. E-mail: lenageise@gmail.com
}

\begin{abstract}
There is still little knowledge about the behavior of the estuarine dolphins and also the way they react to the presence of different types of vessels. The aim of the present study was twofold: to investigate the behavior of estuarine dolphins in four locations in Pernambuco, Brazil, and also their reaction to the presence of common types of nautical crafts. The data of this study resulted from 48 fieldtrips to each of the four localities studied (ports of Recife and Suape, and beaches of Bairro Novo and Piedade), thus totaling 192 days of observations, with approximately 380 hours of actual sampling. Ten types of behavioral activities were counted for Bairro Novo beach and the port areas, but only four for Piedade beach. The greatest flows of boats were recorded in the port of Recife. Fishing boats were the commonest type in the port area of Recife and Bairro Novo beach, while tourist vessels predominated in the port of Suape and Piedade beach. During the observations of encounters between these boats and the estuarine dolphins, neutral reactions predominated for all the vessel types studied. The same type of reaction predominated when the distances at which the interactions between the animals and vessels occurred were correlated.
\end{abstract}

KEY WORDS. Behavioral repertoire; estuarine dolphins; vessels.

RESUMO. O comportamento de Sotalia guianensis (Van Bénéden) em águas costeiras de Pernambuco, Brasil, e uma análise adicional de sua reação ao tráfego de embarcações. Ainda se sabe pouco sobre o comportamento do boto-cinza, assim como a forma pela qual ele reage a diferentes tipos de embarcações. O presente estudo teve dois objetivos: investigar o comportamento dos botos-cinzas em quatro localidades de Pernambuco, Brasil, assim como a reação destes para com as embarcações náuticas comuns. Os dados foram coletados no período de setembro de 2004 a agosto de 2006, no horário das 6 às 17 h. Os dados desta pesquisa resultaram de 48 saídas a campo para cada uma das quatro localidades estudadas (Portos do Recife e Suape, praia de Bairro Novo e Piedade), totalizando 192 dias de observações, sendo aproximadamente 380 horas de amostragens efetivas. Foram contados dez tipos de atividades comportamentais para a praia de Bairro Novo e as áreas portuárias; e apenas quatro para a praia de Piedade. Com relação às embarcações, o maior fluxo foi registrado para o porto do Recife. Os barcos de pesca foram os mais freqüentes nas áreas do porto do Recife e da praia de Bairro Novo, enquanto que no porto de Suape e na praia de Piedade predominaram as embarcações de turismo. Durante as observações dos encontros dos barcos com os botos-cinza, houve uma predominância nas reações neutras para todos os tipos de embarcações estudadas. O mesmo tipo de reação predominou quando relacionadas as distâncias em que ocorreram as interações entre os animais e as embarcações.

PALAVRAS-CHAVE. Boto-cinza; embarcações; repertório comportamental.

Sotalia guianensis (Van Bénéden, 1864) is the small cetacean that is most frequently found along the Brazilian coast, and it has been recorded in estuaries, bays and other protected areas (FLORES 2002). Concentration of small cetaceans in bays is associated with different behaviors that require calm and protected waters. For spinner dolphins, Stenella longirostris (Gray, 1828), in Kealakeakua Bay, Hawaii (Norris \& DoHL 1980) those areas are used for rest, reproduction and the care of calves, 
while for Sotalia guianensis foraging behaviors were registered (e.g. Araújo et al. 2003, Lodi 2003, Torres \& Beasley 2003).

Among delphinids, studies on behavioral patterns have mainly been conducted on Orcinus orca (Linnaeus, 1758) (SIMILA \& UGARTe 1993, SAULITIS et al. 2000), Stenella longirostris (NoRRIs \& Dohl 1980, Silva Jr et al. 2005) and Tursiops truncatus (Montagu, 1821) (WÜRSIG \& WÜrSIg 1979, BeARZI et al. 1999). Their behavioral patterns seem to resemble those observed for Sotalia guianensis (Geise et al. 1999, ARAújo et al. 2003, Souto et al. 2006). However, the wide geographic distribution of this species (DA SILVA \& BEST 1996) and the large variety of environments in which it has already been recorded mean that regional studies become important for investigating if there is variation in the behavioral repertoire between different populations of estuarine dolphins. Pernambuco, for instance, is a state in Northeast Brazil where estuarine dolphins has been poorly studied.

Not only the better knowledge of the behavioral repertoire of cetaceans is of importance but their reaction to boats also deserves immediate attention. This is especially true for a species like the estuarine dolphin which shows site fidelity and lives exclusively in coastal waters (Hetzel \& Lodi 1993, Flores 1999, Azevedo et al. 2004, Rossi-SANTos et al. 2007). Studies have shown that boats disturb cetaceans in different ways (e.g. increasing dive intervals, changing communication and avoiding approaching boats) (see BeJDER \& SAMUELs 2003 for a review). Specifically concerning estuarine dolphins boats may also have negative impact. Pereira et al. (2007) studying the interactions between vessels and estuarine dolphins discovered that cetaceans may change their behavior or avoid the approaching boats. However, it is important to note that the type of boat seems to affect dolphins differently. Constantine et al. (2004, studying bottlenose dolphins), and Pereira et al. (2007) noticed that dolphin-watching tourism vessels caused more disturbance than other nautical crafts. Studies on this topic seem important to provide specific management plans. Unfortunately data are still scarce and, to our knowledge, there is no study involving the disturbance caused by large vessels on estuarine dolphins.

Thus, the aim of the present study was twofold: to investigate the behavior of estuarine dolphins in four locations in Pernambuco, Brazil, and also their reaction to the presence of common types of nautical crafts, including large vessels.

\section{MATERIAL AND METHODS}

This study was developed on the coast of the State of Pernambuco (Fig. 1), in the areas of the Port of Suape (Ipojuca), Piedade beach (Jaboatão dos Guararapes), the Port of Recife (Recife) and Bairro Novo beach (Olinda). The installations of the Port of Suape $\left(8^{\circ} 23^{\prime} \mathrm{S}, 34^{\circ} 57^{\prime} \mathrm{W}\right)$ consist of two harbor areas: an inner dredged area and an outer area, separated naturally by the cordon of barrier reefs that protects the inner area (PORTO DE SuAPE 2007). Piedade beach ( $\left.8^{\circ} 09^{\prime} \mathrm{S}, 34^{\circ} 54^{\prime} \mathrm{W}\right)$ is $5.6 \mathrm{~km}$ long and is influenced by the Jaboatão river (SousA \& Cocentino 2004). The Port of Recife $\left(8^{\circ} 02^{\prime} \mathrm{S} 34^{\circ} 51^{\prime} \mathrm{W}\right)$ is located at the confluence

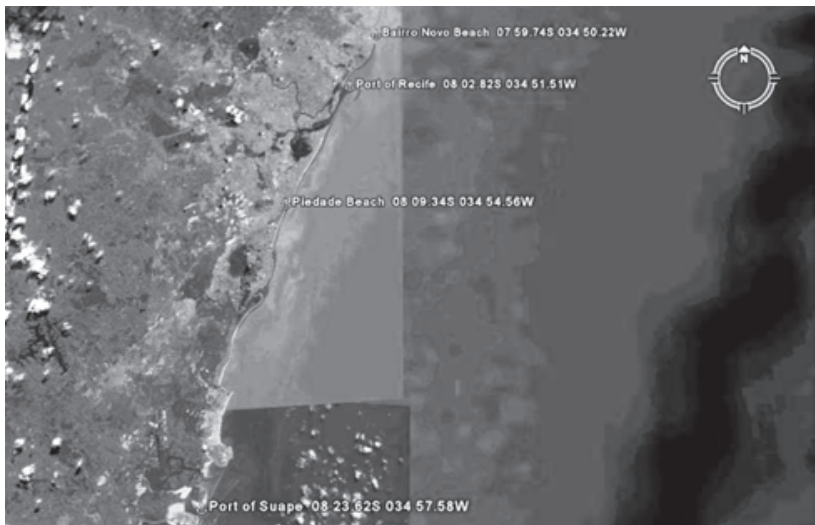

Figure 1. Estuarine dolphin observation locations on the coast of Pernambuco.

of the Capibaribe and Beberibe rivers, and there are two access channels to it (PorTo do Recife 2007). On the coast around Bairro Novo $\left(7^{\circ} 59^{\prime} \mathrm{S}, 34^{\circ} 50^{\prime} \mathrm{W}\right)$, several stretches are protected by parallel half-submerged breakwaters and a ridge perpendicular to the coastline (Pereira et al. 1996).

The data were collected between September 2004 and August 2006, during the hours from 6:00 a.m. to 5:00 p.m., on two consecutive days per month, in each of the four areas studied. There were 48 field trips to each of the four localities. This totaled 192 days of observations and 2,112 hours of sampling efforts, of which approximately 380 hours was effective sampling, corresponding to the behavioral records of the estuarine dolphins.

The observations were made at fixed points and were noted down on field record cards: date, numbers of estuarine dolphins, frequencies of behavioral events among adults and calves, types and quantities of boats and the reactions of the estuarine dolphins to them. The records were made continuously, with all the information accumulated over 15-minute intervals. In forming the study groups, it was decided only to differentiate between adult and calves individuals, without differentiating the counts between juveniles and younger calves (SPINELli et al. 2002). Because of the small size of the species, in relation to other species in the same family, differentiation into three age groups is not clear enough to be done at a distance, considering that distant observation is necessary on some occasions. The basis for identifying the behavioral patterns of the estuarine dolphins was the studies by GeIse (1991), Araújo et al. (2003) and Souto et al. (2006).

The vessels were divided into six categories: fishing boats (with engines; used for fishing activities, such as powered canoes and motorboats); tourist or leisure boats (small and mediumsized, with engines, including launches and jet skis); sailing boats (no engine; moved only by the strength of the winds, such as sailing rafts, sailing and paddle canoes, and yachts); ships (largesize, with engines, such as cargo ships and passenger yachts);

Revista Brasileira de Zoologia 25 (1): 1-9, March, 2008 
tugs (with engines, used for maneuvering ships inside port areas); and dredgers (with engines, used for dredging port areas). It must be emphasized that no vessels were used for the purposes of watching the estuarine dolphins in any of the studies localities, and the tourist boats were only using these areas for transit.

The behavioral reactions of the estuarine dolphins following interaction with the vessels were classified as positive, neutral or negative (Pereira et al. 2007). A positive reaction involved the approaching of those cetaceans to the boats. The dolphins were deemed to show neutral reactions when there was no perceptible change in the animals' behavior, i.e., heading to or away from boats. The reaction was deemed to be negative when dolphins moved away from boats (Pereira et al. 2007). In identifying these reactions, with the exception of when ships were together with tugs, data relating to the presence of more than one vessel in the area at the same time were discarded. Thus, only the information referring to the presence of a single vessel during encounters with the estuarine dolphins was taken into consideration.

To be able to compare the behavioral changes among the animals according to how close the vessels were, the distance between the vessel and the dolphins was calculated by visual estimation. The maximum distance considered, from the observation point to where the animals and vessel were, was $300 \mathrm{~m}$. A beacon $300 \mathrm{~m}$ from the fixed point in the two ports was taken as the reference for assessing these distances.

For the statistical analysis, the mean numbers of behavioral patterns and vessels per month were used. Certain statistical tests were utilized for evaluating the degree of significance of the results. Friedman's test was used to investigate whether there were any significant differences between the numbers of behavioral patterns in the groups (with and without calves) per area, and to investigate the significance levels between the frequencies of the different types of vessel per area. Dunn's multiple comparison test was used to indicate where the significant differences indicated by Friedman's test were, by means of pair-bypair correlations between each of the behavioral patterns and between the vessels for each locality. Wilcoxon's test aimed to test the significance of the numbers of vessels if they were found only two of the four localities studied, when it was not possible to use Friedman's test, and also for determining the significance of the behavioral reactions with regard to the different types of vessels. Fisher's test was used to investigate whether there were any significant differences in the behavioral reactions of the estuarine dolphins in the presence of different types of vessels, according to the distances between them. The significance level of $p \leqslant 0.05$ was adopted (Siegel 1975), and the GraphPad InStat 3 software was used for the analyses.

\section{RESULTS}

The most frequent group sizes, formed solely of adult animals, were two individuals for Bairro Novo beach (33.33\%) and Piedade beach (50\%), and five for the port areas of Suape (36.36\%) and Recife (31.82\%) (Tab. I). The largest groups, containing nine individuals, occurred in the port areas. On 46 occasions a single calf was observed with the adults. In no occasion there was more than one calf with the adults.

The categories for the behavioral patterns displayed by the estuarine dolphins were the same for the different localities, except for Piedade beach, but the frequencies of their occurrence varied. The proportions of behavioral pattern observations for the different localities were $66.36 \%(\mathrm{n}=2518)$ for the port of Recife, $21.55 \%(\mathrm{n}=818)$ for the port of Suape, $11.54 \%(n=438)$ for Bairro Novo beach and $0.55 \%(n=21)$ for Piedade beach. Ten types of behavioral activities were counted for Bairro Novo beach and the port areas: tailslap, porpoising, total leaping, spy-hopping, chase, partial leaping, object controlling, surfing, pectoral and somersault, and four for Piedade

Table I. Frequencies of numbers of adults per month, in each of the studied areas.

\begin{tabular}{|c|c|c|c|c|c|c|c|c|c|c|c|c|}
\hline \multirow[t]{2}{*}{ Months } & \multicolumn{3}{|c|}{ Port of Recife } & \multicolumn{3}{|c|}{ Port of Suape } & \multicolumn{3}{|c|}{ Bairro Novo Beach } & \multicolumn{3}{|c|}{ Piedade Beach } \\
\hline & 2004 & 2005 & 2006 & 2004 & 2005 & 2006 & 2004 & 2005 & 2006 & 2004 & 2005 & 2006 \\
\hline January & - & 7 & 5 & - & 5 & 3 & - & 5 & 0 & - & 0 & 0 \\
\hline February & - & 5 & 3 & - & 5 & 9 & - & 3 & 5 & - & 3 & 2 \\
\hline March & - & 9 & 5 & - & 2 & 2 & - & 3 & 0 & - & 0 & 2 \\
\hline April & - & 3 & 5 & - & 4 & 5 & - & 0 & 2 & - & 3 & 0 \\
\hline May & - & 0 & 2 & - & 6 & 5 & - & 0 & 0 & - & 2 & 3 \\
\hline June & - & 5 & 0 & - & 0 & 5 & - & 0 & 0 & - & 0 & 0 \\
\hline July & - & 5 & 3 & - & 5 & 0 & - & 0 & 0 & - & 4 & 0 \\
\hline August & - & 3 & 6 & - & 4 & 5 & - & 0 & 0 & - & 0 & 0 \\
\hline September & 4 & 7 & - & 3 & 4 & - & 2 & 2 & - & 0 & 0 & - \\
\hline October & 4 & 6 & - & 4 & 4 & - & 1 & 5 & - & 2 & 4 & - \\
\hline November & 5 & 6 & - & 5 & 4 & - & 3 & 0 & - & 0 & 0 & - \\
\hline December & 6 & 7 & - & 3 & 3 & - & 2 & 4 & - & 2 & 0 & - \\
\hline
\end{tabular}


beach: porpoising, total leaping, partial leaping and surfing.

Among the behavioral categories, tailslap was the most frequent type at Bairro Novo beach $(\mathrm{n}=193 ; 43.61 \%)$ and in the ports of Suape $(\mathrm{n}=307 ; 37.04 \%)$ and Recife $(\mathrm{n}=790$; $30.38 \%$ ), while total leaping was the activity observed most frequently at Piedade beach $(n=14 ; 66.67 \%)$. Among the behavioral activities performed by the calves, total leaping was the activity viewed most frequently in the port areas of Recife $(\mathrm{n}=86 ; 66.67 \%)$ and Suape $(\mathrm{n}=22 ; 50 \%)$. On the other hand, the spy-hopping activity was predominant $(n=4 ; 44.44 \%)$. At Piedade beach, a single calf was observed, and this individual was in transit, i.e. simply passing through the area (Fig. 2).

For the adults, there were significant differences in behavioral patterns between the areas of Recife and Piedade; Suape and Piedade; and Recife and Bairro Novo (Tab. II). There were no significant differences in the other comparisons between areas regarding behavioral patterns ( $p>0.05$ ). Regarding the calves, there were also no significant differences in behavioral patterns between the areas studied ( $p>0.05)$, and this was probably due to the small sample size.

Among the 4172 vessels recorded, the greatest flow was to and from the port of Recife $(n=2390)$, followed by port of Suape $(\mathrm{n}=1340)$, Bairro Novo beach $(\mathrm{n}=262)$ and Piedade beach $(n=180)$. Fishing boats were the commonest type in the port of Recife $(n=1708)$ and Bairro Novo beach $(n=121)$, while in the port of Suape $(\mathrm{n}=401)$ and Piedade beach $(\mathrm{n}=$ 127) tourist boats predominated (Fig. 3).

There were significant differences in the frequency of sightings of fishing boats between the areas of Recife and Bairro
Novo; Suape and Bairro Novo; and Suape and Piedade. Analysis of the frequency of tourist boats showed significant differences between the port of Recife and Bairro Novo beach; port of Suape and Bairro Novo beach; and port of Suape and Piedade beach. For the frequency of sailing boats, there were significant differences between the port of Recife and Piedade beach and between the ports of Recife and Suape (Tab. III).

Tugs $(\mathrm{N}=12, \mathrm{~T}=-75.5, \mathrm{p}<0.01)$, dredgers $(\mathrm{N}=12, \mathrm{~T}=-$ 74.5, $\mathrm{p}<0.01)$ and ships $(\mathrm{N}=12, \mathrm{~T}=-57.5, \mathrm{p}<0.05)$ were only seen in the port area, with a significantly greater presence of these in the port of Suape.

During the observations of encounters between boats and the estuarine dolphins, there was significant predominance of neutral reactions for all the types of vessels studied $(\mathrm{N}=7, \mathrm{~T}=0$, $\mathrm{p}<0.05$ ). Tourist boats were the type for which they demonstrated greatest negative response (Fig. 4). With regard to the distance at which the animals met the boats, there was no significant difference in relation to any type of vessel, with $\mathrm{p}>0.05$ using Fisher's test (Fig. 5). Positive interactions between dolphins and boats were absent as dolphins did not headed to the boats.

\section{DISCUSSION}

Formations of small groups composed of two estuarine dolphins were most common in the open beach areas (Bairro Novo and Piedade) and groups of five individuals in the closed port areas (Recife and Suape). Similar result regarding the small size of groups were found in Dolphin Bay, in the State of Rio Grande do Norte (Araújo et al. 2003), where the most frequent number of animals observed by group was four individuals.

Table II. Dunn's test relating to the behavioral activities performed by adult dolphins, between the different studied areas.

\begin{tabular}{llll}
\hline \multicolumn{1}{c}{ Behaviors } & \multicolumn{1}{c}{ Recife - Piedade } & \multicolumn{1}{c}{ Suape - Piedade } & Recife - Bairro Novo \\
\hline Tailslap & $\left|R_{R}-R_{p}\right|=27.5 ; N=12 ; p<0.001$ & $\left|R_{S}-R_{p}\right|=17.5 ; N=12 ; p<0.05$ & \\
Porpoising & $\left|R_{R}-R_{p}\right|=23.5 ; N=12 ; p<0.01$ & $\left|R_{S}-R_{p}\right|=19 ; N=12 ; p<0.05$ & $\left|R_{R}-R_{B}\right|=18.5 ; N=12 ; p<0.05$ \\
Total leaping & $\left|R_{R}-R_{p}\right|=21 ; N=12 ; p<0.01$ & & $\left|R_{R}-R_{B}\right|=18.5 ; N=12 ; p<0.05$ \\
Spy-hopping & $\left|R_{R}-R_{p}\right|=25.5 ; N=12 ; p<0.001$ & & \\
Chase & $\left|R_{R}-R_{p}\right|=21 ; N=12 ; p<0.01$ & $\left|R_{S}-R_{P}\right|=18 ; N=12 ; p<0.05$ & \\
Partial leaping & $\left|R_{R}-R_{p}\right|=25 ; N=12 ; p<0.001$ & & \\
Object controlling & $\left|R_{R}-R_{p}\right|=19.5 ; N=12 ; p<0.05$ & & \\
\hline
\end{tabular}

$\left(R_{R}\right)$ Port of Recife, $\left(R_{B}\right)$ Bairro Novo beach, $\left(R_{p}\right)$ Piedade beach, $\left(R_{S}\right)$ port of Suape.

Table III. Dunn's test associating the fishing, tourist and sailing boats between the different studied areas.

\begin{tabular}{llll}
\hline \multicolumn{1}{c}{ Areas } & \multicolumn{1}{c}{ Fishing boats } & Tourist boats & Sailing boats \\
\hline Recife vs. Bairro Novo & $\left|R_{R}-R_{B}\right|=23 ; N=12 ; p<0.01$ & $\left|R_{R}-R_{B}\right|=23 ; N=12 ; p<0.01$ & \\
Recife vs. Piedade & $\left|R_{R}-R_{P}\right|=35 ; N=12 ; p<0.001$ & & $\left|R_{R}-R_{p}\right|=27.5 ; N=12 ; p<0.001$ \\
Recife vs. Suape & & & $\left|R_{R}-R_{S}\right|=26.5 ; N=12 ; p<0.001$ \\
Suape vs. Piedade & $\left|R_{S}-R_{p}\right|=21 ; N=12 ; p<0.01$ & $\left|R_{S}-R_{P}\right|=19 ; N=12 ; p<0.05$ & \\
Suape vs. Bairro Novo & & $\left|R_{S}-R_{B}\right|=26 ; N=12 ; p<0.001$ & \\
\hline
\end{tabular}

$\left(R_{R}\right)$ Port of Recife, $\left(R_{B}\right)$ Bairro Novo beach, $\left(R_{p}\right)$ Piedade beach, $\left(R_{S}\right)$ port of Suape.

Revista Brasileira de Zoologia 25 (1): 1-9, March, 2008 


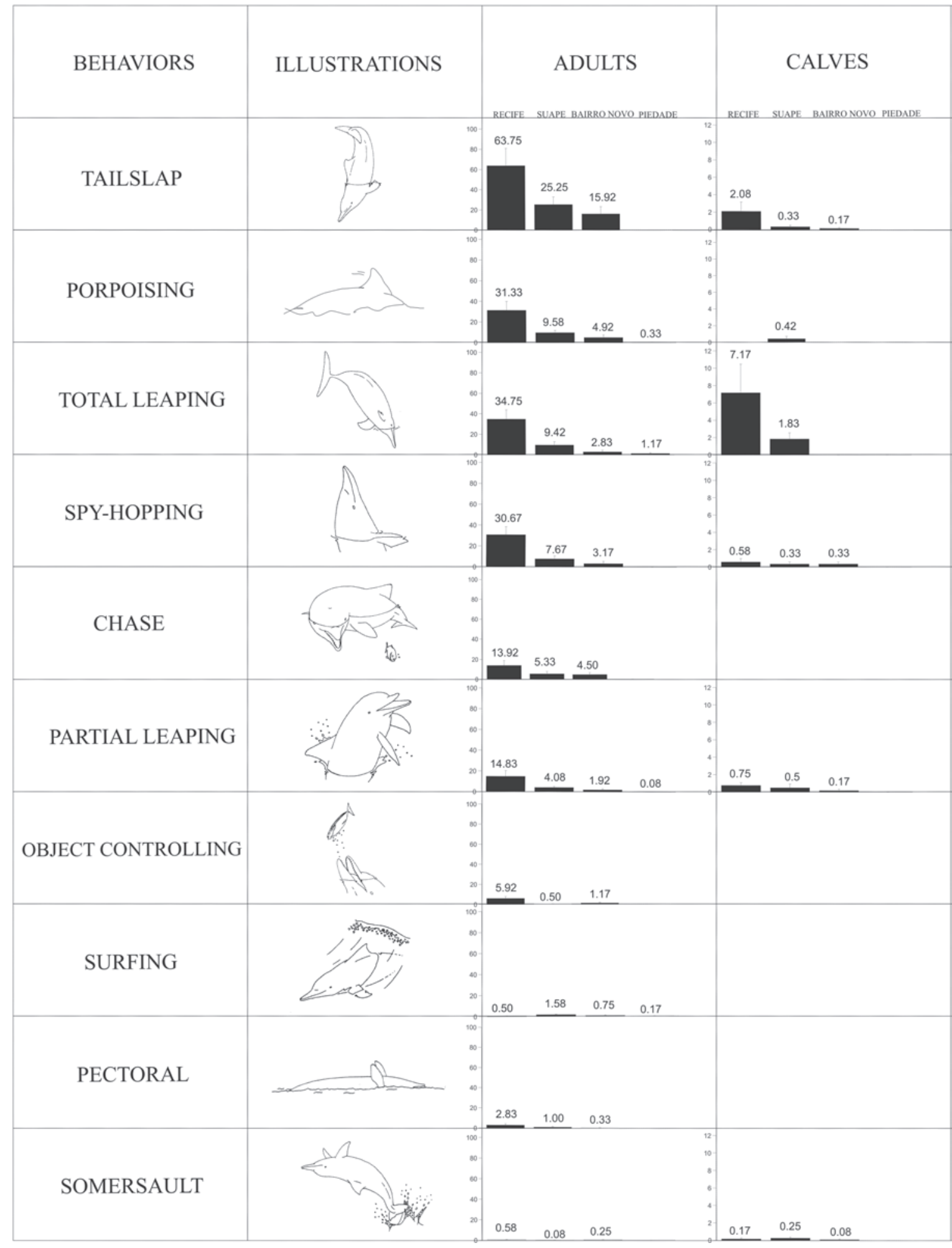

Figure 2. Mean number of occurrence of different behavioral activities among adults and calves estuarine dolphins in Pernambuco, between September 2004 and August 2006. 


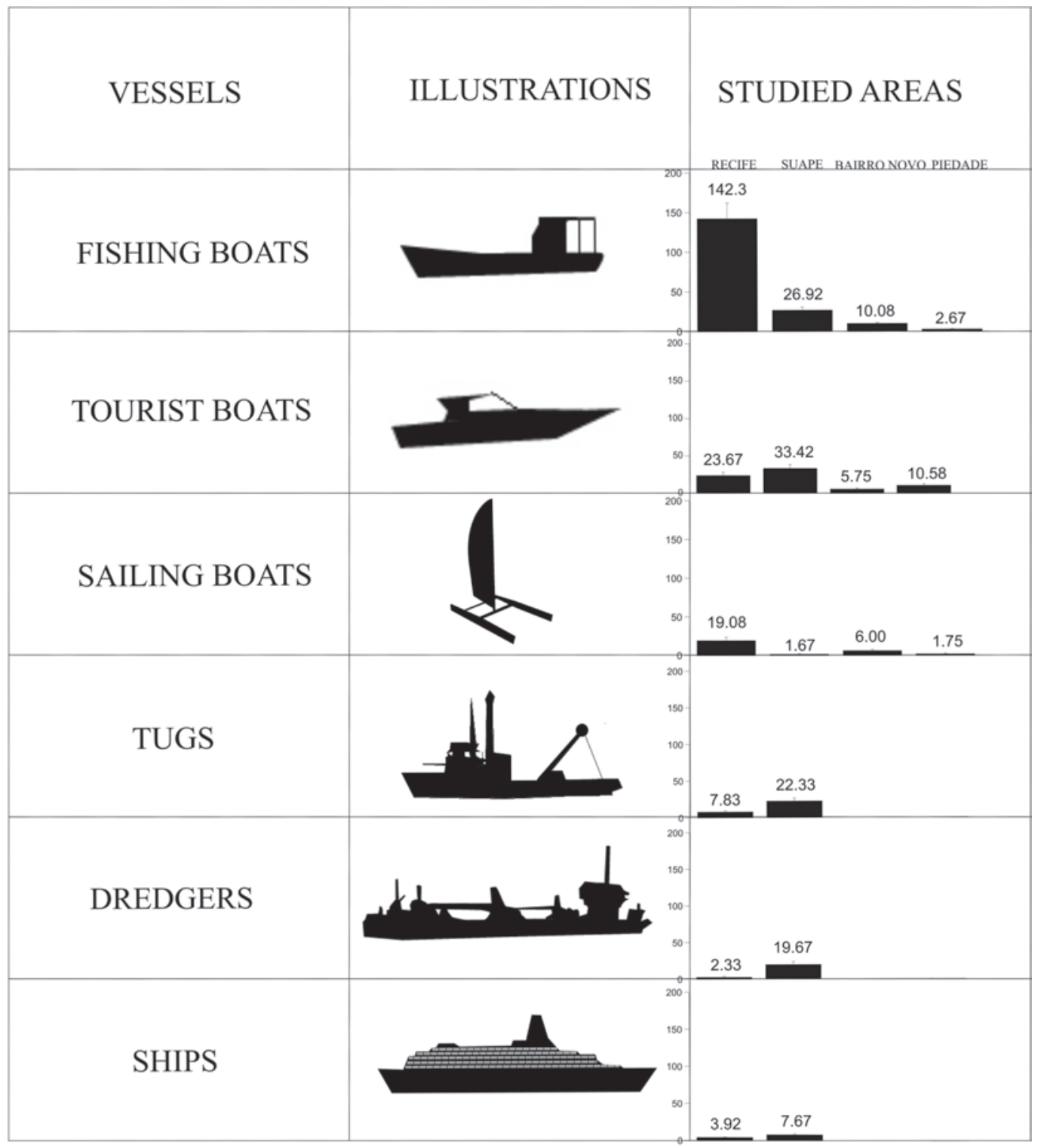

Figure 3. Mean number of occurrence of different types of vessels recorded in Pernambuco, between September 2004 and August 2006.

Groups containing two to ten estuarine dolphins were most commonly sighted in Guanabara Bay, in the State of Rio de Janeiro (AzEvEDo et al. 2005). On the other hand, larger groups containing 31 to 40 individuals were predominantly observed in Paraty Bay, State of Rio de Janeiro (Lodi 2003), and North Bay in the State of Santa Catarina, where Flores \& Fontoura (2006) detected greatest frequency of groups containing between 60 and 80 individuals.

It seems that there is a latitude gradient in group size along the Brazilian coast, with a tendency towards larger groups in the south and southeast and towards smaller groups in the north- east. The differences found may be related to a variety of factors, such as the oceanographic and physiographic characteristics of each area and human activities (with intense vessel traffic) (PARENTE et al. 2007). Another factor that may influence the size of the groups is the presence of predators or other species of small cetaceans, which may result in aggressive interactions. There is evidence of antagonistic interaction between Sotalia guianensis and Tursiops truncatus, which may contribute towards the formation of large groups (WEDEKIN et al. 2004). It also seems that the formation of larger groups may be related to greater availability and abundance of prey (FLORES \& FonTOuRA 2006). 

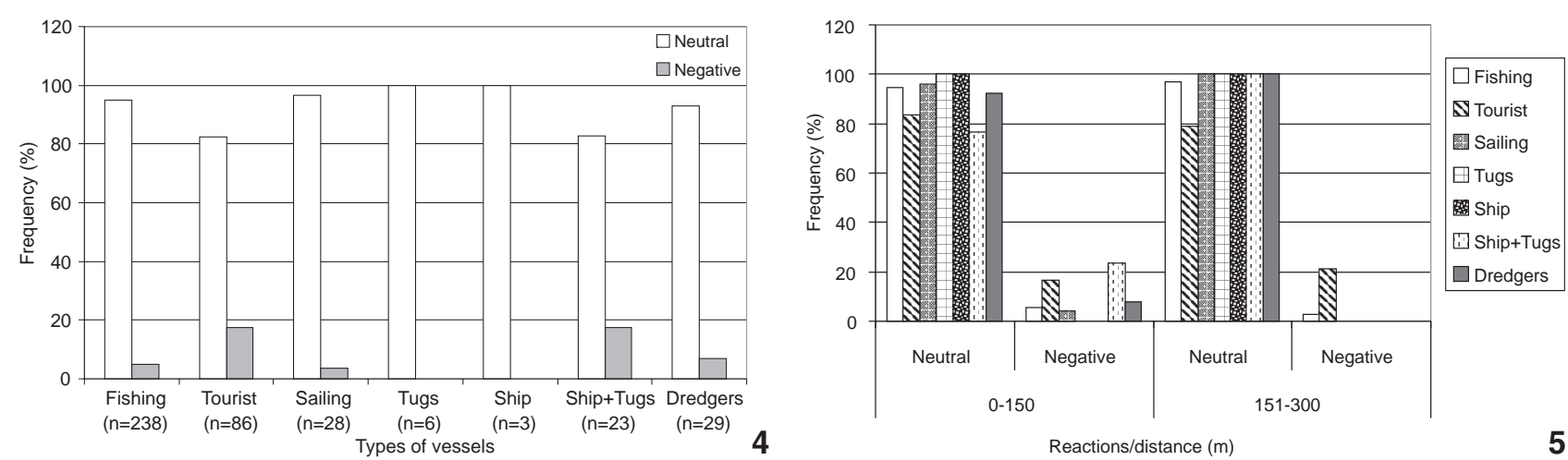

Figures 4-5. Relative frequencies of the reactions of estuarine dolphins, in relation to the different types of vessels recorded (4) and considering distance (5) in Pernambuco, between September 2004 and August 2006.

Calves were sighted in the present study in almost all months of the year, particularly in the port areas, where there was also greater incidence of adults. This indicates that these localities are possibly being used as rearing areas. There are records of sightings of calves throughout the year from North Bay, Santa Catarina (Daura-Jorge et al. 2005); Paraty and Guanabara, Rio de Janeiro (Lodi 2003, Azevedo et al. 2005); Dolphin Bay, Rio Grande do Norte (Araújo et al. 2003) and the Cananéia estuary region, São Paulo (GeIse et al. 1999). The presence of calves throughout the year corroborates the findings of Rosas \& Monteiro-Filho (2002), according to whom the females did not present a well-defined ovulation period and the males did not present seasonal variation in testicular activity.

The presence of calves in the present study was noted during the development of the adults' activities, and it was seen that the calves' behavioral activities seemed to have play purposes. This was also observed in Dolphin Bay (Rio Grande do Norte), where on very rare occasions the calves took part in chases and, when they did so, the context seemed to be play and not foraging (SPINELLI et al. 2002).

The fact that young dolphins do not actively participate in foraging behavioral patterns may be related to dependence on food provision by their mothers (MonTeiro et al. 2006). However, the presence of the calves during hunting activities with the adults may indicate a type of learning and training of their behavior that will be used in the next stages of their lives (NOWACEK 2002, SPINELLI et al. 2002, LODI 2003), as well as a form of protection, meaning that the adults have to take the calves with them.

The greater frequencies of certain behavioral activities performed by the calves on the coast of Pernambuco (leaping, tailslap and spy-hopping) were similar to what was found among calves in Cananéia, State of São Paulo (Geise et al. 1999). In a general manner, the behavioral activities performed by the adults and calves in Pernambuco were similar.

Interpretations of the functions of behavioral events are very subjective, and such interpretations may fit into a variety of contexts. Some behavioral strategies may also be involved in the transition from one particular activity to another, thereby performing an important role in the communications during such activities. For example, leaping may be related to other behavioral patterns such as movement from place to place or fishing, and also may be part of types of play activity involved in the learning process (Geise 1991, SPINeLli et al. 2002).

The sampling locations of the present study, particularly the ports, are areas of intense boat traffic, including large vessels. These boats move at constant speeds on predictable courses and do not make attempts to physically contact the animals, but often go through the areas where groups of estuarine dolphins are to be found. For these reasons, the dolphins apparently show a lack of interest in the boats (Constantine et al. 2004, Mattson et al. 2005, Stensland \& Berggren 2007). In addition, particularly with regard to tourist boats with high-powered engines, another probable reason for this is that these animals are not targets for these boats, since they rapidly go through these areas, using them only for transit and not for dolphin-watching activities. No studies describing interactions of estuarine dolphins with ships, tugs or dredgers were found in the literature. From the present study, it was seen that the estuarine dolphins showed neutral reactions independently of the distance at which they met the vessels. The boats in the areas studied did not seem to have much effect on the animals' presence, possibly because they did not target at the dolphins (Constantine et al. 2004, STENsland \& Berggren 2007). When boats keep the same speed, which corresponds to unchanging noise levels emitted by the engines, the behavioral patterns displayed by Sotalia guianensis are also unchanged (SIMÃo et al. 2000).

However, Nichols et al. (2001) noticed that dolphins did not change their behavior in the presence of dolphin-watching boats or people swimming with them. They believed that a learning process had taken place, such that the dolphins perceived that the humans did not represent a threat (Nichols et al. 2001).

Unfortunately, the term habituation has been used without being based on appropriate experimental design features (Bejder et al. 2006). As a consequence, conclusions based on this 
learning process can be misleading. For example, studies on dolphins that refer to habituation usually do not take into account that more sensitive individuals may have departed from a certain region as a response to the presence of boats before the onset of investigation (BEJDER et al. 2006). Moreover, the high sound frequencies emitted by launch and inflatable boat engines are believed to be one of the factors causing most disturbances to Indo-Pacific humpback dolphins Sousa chinensis (Osbeck, 1765) (Leung \& Leung 2003). Even when assuming that habituation may occur, the motor noise may cause serious audition problems to the dolphins (Richardson \& WuRSIG 1997). It is worth of note that hearing impairment among the estuarine dolphins was presented as a possible factor related to decreased frequency of negative behavioral reactions and increased neutral reactions in North Bay, Santa Catarina (Pereira et al. 2007).

Many cetaceans continue to frequent the same localities, not because they are not affected, but because they depend on those places to maintain their activities (WATKINS 1986, Blane \& JaAkson 1994, Richardson \& Wursig 1997, Lusseau 2004). This might well be the case for the estuarine dolphins as they show site fidelity (Hetzel \& Lodi 1993, Flores 1999, Azevedo et al. 2004, Rossi-SANTOS et al. 2007).

Although no tourist activities for observing cetaceans are being developed in these studied areas, it is important to assess the impact of boat traffic before such activities might start. More detailed studies would be needed for better comprehension of the potential impact of such activities on dolphin populations and in order to establish suitable regulations and policies for conserving this species.

\section{ACKNOWLEDGEMENTS}

We are grateful to the two anonymous referees for valuable suggestions that improved the manuscript. To Walter Blossey and Luiz G. Mascarenhas for authorizing the observations in the Port and Industrial Complex of Suape, which made it possible to carry out this work. To Weber Silva, James Cantarelli and André Nascimento for the illustrations. To the university staff; Carolinne Ramos, Clayton Fernandes, Eric Nascimento, Gislay S. Galdino, Juliana G. Arcelino, Kalyne Rodrigues, Michelly Oliveira, Milena Monteiro, Samia Monteiro e Sueny Paloma Santos, for their help in the field work. The CAPES/UFPE provided a scholarship to JPA. The CNPq provided research grants to LG and MEA.

\section{LITERATURE CITED}

Araújo, J.P.; J.Z. de O. Passavante \& A.S. Souto. 2003. Behavior of the estuarine dolphin, Sotalia guianensis, at Dolphin Bay Pipa - Rio Grande do Norte - Brazil. Tropical Oceanography 31 (2): 101-112.

Azevedo, A.F.; J. Lailson-Brito Jr; H.A. Cunha \& M. van Sluys. 2004. A note on site fidelity of marine tucuxis (Sotalia fluviatilis) in Guanabara Bay, southeastern Brazil. Journal of Cetacean Research and Management 6 (3): 265-268.
Azevedo, A.F.; S.C. Viana; A.M. Oliveira \& M. van Sluys. 2005. Group characteristics of marine tucuxi (Sotalia fluviatilis) in Guanabara Bay, south-eastern Brazil. Journal of the Marine Biological Association of the United Kingdom 85: 209-212.

Bearzi, G.; E. Politi \& G.N. Sciara. 1999. Diurnal behavior of freeranging bottlenose dolphins in the Kvarneric (Northern Adriatic Sea). Marine Mammal Science 15 (4): 1065-1097.

Bejder, L. \& A. SAmuels. 2003. Evaluating the effects of naturebased tourism on cetaceans, p. 229-256. In: N. Gales; M. Hindell \& R. Kirkwood (Eds). Marine Mammals: Fisheries, Tourism and Management Issues. Australia, CSIRO Publishing, 460p.

Bejder, L.; A. Samuels; H. Whitehead; N. Gales; J. Mann; R. Connor; M. Heithaus; J. Watson-Capps; C. Laherty \& M. Krutzen. 2006. Decline in Relative Abundance of Bottlenose Dolphins Exposed to Long-Term Disturbance. Conservation Biology 20 (6): 1791-1798.

Blane, J.M. \& R. JAAKSON. 1994. The impact of ecotourism boats on the St. Lawrence beluga whales. Environmental Conservation 21(3): 267-269.

Constantine R.; D.H. Brunton; T. Dennis. 2004. Dolphin-watching tour boats change bottlenose dolphin (Tursiops truncatus) behaviour. Biological Conservation 117: 299-307.

DA SiLva, V.M.F. \& R.C. BEST. 1996. Sotalia fluviatilis. Mammalian Species 527: 1-7.

Daura-Jorge, F.G.; L. Wedekin; V.Q. Piacentini \& P.C. Simões-Lopes. 2005. Seasonal and daily patterns of group size, cohesion and activity of the estuarine dolphin, Sotalia guianensis (P.J. Van Bénéden) (Cetacea, Delphinidae), in southern Brazil. Revista Brasileira de Zoologia 22 (4): 1014-1021.

Flores, P.A.C. 1999. Preliminary results of a photoidentification study of the marine tucuxi Sotalia fluviatilis in southern Brazil. Marine Mammal Science 15 (3): 840-847.

Flores, P.A.C. 2002. Tucuxi Sotalia fluviatilis, p. 1267-1269. In: W.F. Perrin; B. Würsig \& J.G.M. Thewissen (Eds). Encyclopedia of marine mammals. Cambridge, Academic Press, 1414p.

Flores, P.A.C. \& N.F. Fontoura. 2006. Ecology of marine tucuxi, Sotalia guianensis, and bottlenose dolphin, Tursiops truncatus, in Baía Norte, Santa Catarina State, southern Brazil. LAJAM 5 (2): 105-115.

GeIse, L. 1991. Sotalia guianensis (Cetacea, Delphinidae) population in the Guanabara Bay, Rio de Janeiro, Brazil. Mammalia 55 (3): 371-379.

Geise, L.; N. Gomes \& R. Cerqueira. 1999. Behaviour, habitat use and population size of Sotalia fluviatilis (Gervais, 1853) (Cetacea, Delphinidae) in the Cananéia estuary region, São Paulo, Brazil. Revista Brasileira de Biologia 59 (2): 183-194.

Hetzel, B. \& L. Lodi. 1993. Baleias, botos e golfinhos: guia de identificação para o Brasil. Rio de Janeiro, Nova Fronteira, 279p.

Leung, S.N. \& S. Leung. 2003. Behavioral response of Indo-Pacific humpback dolphin (Sousa chinensis) to vessel traffic. Marine Environmental Research 56: 555-567. 
LoDI, L. 2003. Tamanho e composição de grupo dos botos-cinza, Sotalia guianensis (van Bénéden, 1864) (Cetacea, Delphinidae), na Baía de Paraty, Rio de Janeiro, Brasil. Atlântica 25 (2): 135-146.

LusSEAU, D. 2004. The hidden cost of tourism: detecting longterm effects of tourism using behavioral information. Ecology and Society 9 (1): 2. Available in the World Wide Web at: http://www.ecologyandsociety.org/vo19/iss1/art2 [Accessed in 21/X/2005]

MatTson, M.C.; J.A. Thomas \& D.S.T. Aubin. 2005. Effects of Boat Activity on the Behavior of Bottlenose Dolphins (Tursiops truncatus) in Waters Surrounding Hilton Head Island, South Carolina. Aquatic Mammals 31 (1): 133-140.

Monteiro, M.S.; A. Souto \& L.F. Nascimento. 2006. Comparações entre os comportamentos de forrageio nas diferentes faixas etárias do boto-cinza (Sotalia guianensis) (Cetacea; Delphinidae) na Baía dos Golfinhos, Praia de Pipa, RN, Brasil. Revista de Etologia 8 (1): 13-25.

Nichols, C.; G. Stone; A. Hutt; J. Brown \& A. Yoshinaga. 2001. Observations of interactions between Hectors dolphins (Cephalorhynchus hectori), boats and people at Akaroa Harbour, New Zealand. Science for Conservation 178: 1-49.

NoRRIs, K.S. \& T.P. DoHL. 1980. The behavior of the hawaiian spinner porpoise, Stenella longirostris. Fishery Bulletin 77: 821-849.

NowACEK, D.P. 2002. Sequential foraging behaviour of bottlenose dolphins, Tursiops truncatus, in Sarasota Bay, FL. Behaviour 139 (9): 1125-1145.

Parente, C.L.; J.P. Araújo \& M.E. Araújo. 2007. Diversity of cetaceans as tool in monitoring environmental impacts of seismic surveys. Biota Neotropica 7 (1): 1-7. Available in the World Wide Web at: http://www.biotaneotropica.org.br/ v7n1 [Accessed in 20/IV/2007].

Pereira, L.C.C.; P.N. Coutinho; S.J. Macedo \& R.A.A.M. Costa. 1996. Efeitos de estruturas de proteção costeira nas praias de Casa Caiada e Rio Doce - PE, Brasil. Trabalhos Oceanográficos 24: 19-37.

Pereira, M.G.; M. Bazzalo \& P.A.C. Flores. 2007. Reações comportamentais de Sotalia guianensis (Cetacea, Delphinidae) durante encontros com embarcações na Baía Norte de Santa Catarina. Revista Brasileira de Zoociências 9 (2): 123-135.

Porto de Suape. 2007. Características do Porto de Suape. Available in the World Wide Web at: http://www.suape.pe. gov.br [Accessed in 21/I/2007]

Porto do Recife. 2007. Características do Porto do Recife. Available in the World Wide Web at: http://www.portodo recife.pe.gov.br [Accessed in 21/I/2007]

Richardson, W.J. \& B. Würsig. 1997. Influences of man-made noise and other human actions on cetacean behaviour. Marine and Freshwater Behavior and Physiology 29 (1/ 4): 183-209.
Rosas, F.C.W. \& E.L.A. Monteiro-Filho. 2002. Reproduction of the estuarine dolphin (Sotalia guianensis) on the coast of Paraná, southern Brazil. Journal of Mammalogy 83 (2): 507-515.

Rossi-SANTOs, M.R.; L.L. WedeKIn \& E.L.A. Monteiro-Filho. 2007. Residence and site fidelity of Sotalia guianensis in the Caravelas River Estuary, eastern Brazil. Journal of the Marine Biological Association of the United Kingdom 87: 207-212.

Saulitis, E.; C. Matkin; L. Barrett-Lennard; K. Heise \& G. Ellis. 2000. Foraging strategies of sympatric killer whale (Orcinus orca) populations in Prince William Sound, Alaska. Marine Mammal Science 16 (1): 94-109.

SIEGEL, S. 1975. Estatística não paramétrica para as ciências do comportamento. São Paulo, Nacional, 350p.

Silva JR, J.M.; F.J.L. Silva \& I. SaZima. 2005. Rest, nurture, sex, release and play: diurnal underwater behaviour of the spinner dolphin at Fernando de Noronha Archipelago, SW Atlantic. Journal of Ichthyology and Aquatic Biology 9: 161-176.

SimÃo, S.M.; J.L.A. Pizzorno; V.N. Perry \& S. Siciliano. 2000. Aplicação da técnica de fotoidentificação do boto-cinza, Sotalia fluviatilis (Cetacea, Delphinidae) da Baía de Sepetiba. Floresta e Ambiente 7 (1): 31-39.

Simila, T. \& F. Ugarte. 1993. Surface and underwater observations of cooperatively feeding killer whales in northern Norway. Canadian Journal of Zoology 71: 1494-1499.

Sousa, G.S. \& A.L.M. Cocentino. 2004. Macroalgas como indicadoras da qualidade ambiental da Praia de Piedade PE. Tropical Oceanography 32 (1): 1-22.

Souto, A.; J.P. Araújo; L. Geise \& M.E. Araújo. 2006. The surface behavior of the estuarine dolphin in Baía dos Golfinhos, RN, Brazil: a field and comparative study. Revista Brasileira de Zoociências 8 (2): 183-192.

Spinelui, L.H.P.; L.F. Nascimento \& M.E. Yamamoto. 2002. Identificação e descrição da brincadeira em uma espécie pouco estudada, o boto cinza (Sotalia fluviatilis), em seu ambiente natural. Estudos de Psicologia 7 (1): 165-171.

Stensland, E. \& P. Berggren. 2007. Behavioural changes in female Indo-Pacific bottlenose dolphins in response to boat-based turism. Marine Ecology Progress Series 332: 225-234.

Torres, D. \& C.R. Beasley. 2003. Pattern of use a small bay in northern Brazil by Sotalia guianensis (Cetacea: Delphinidae). Amazoniana 17 (3/4): 586-597.

WAtKINS, W.A. 1986. Whale reactions to human activities in Cape Cod waters. Marine Mammal Science 2: 251-262.

Wedekin, L.L.; F.G. Daura-Jorge \& P.C. Simões-Lopes. 2004. An aggressive interaction between bottlenose dolphins (Tursiops truncatus) and estuarine dolphins (Sotalia guianensis) in Southern Brazil. Aquatic Mammals 30 (3): 391-397.

WÜrsig, B \& M. WÜrsig. 1979. Behavior and ecology of the bottlenose dolphin, Tursiops truncatus, in the South Atlantic. Fishery Bulletin 77 (2): 399-412.

Received in 30.VIII.2007; accepted in 06.III.2008. 